\title{
ArKadiusz LACH
}

Uniwersytet Mikołaja Kopernika w Toruniu

\section{OCHRONA WYKONYWANIA ZAWODU JAKO NOWY ŚRODEK ZAPOBIEGAWCZY W KODEKSIE POSTĘPOWANIA KARNEGO*}

\section{WPROWADZENIE}

Ustawą z 31 marca 2020 r. ${ }^{1}$ wprowadzono do procedury karnej nowy środek zapobiegawczy, zakres stosowania którego rozszerzono następnie ustawą z 19 czerwca 2020 r. ${ }^{2}$ Uregulowany w art. 276a k.p.k. środek wykazuje istotne różnice w stosunku do wcześniej wprowadzonych środków zapobiegawczych, stąd celowe jest przeanalizowanie jego funkcji, zakresu podmiotowego ochrony, przesłanek stosowania, rodzaju orzekanych zakazów, powiązania z poręczeniem majątkowym oraz okresu

* Artykuł prezentuje wyniki badań przeprowadzonych w ramach grantu Narodowego Centrum Nauki nr 2017/25/B/HS5/01308 pt. Prewencja indywidualna jako uzasadnienie wprowadzenia i stosowania instytucji karnoprocesowych.

1 Ustawa z 31 marca 2020 r. o zmianie ustawy o szczególnych rozwiązaniach związanych z zapobieganiem, przeciwdziałaniem i zwalczaniem COVID-19, innych chorób zakaźnych oraz wywołanych nimi sytuacji kryzysowych oraz niektórych innych ustaw (Dz. U. z 2020 r. poz. 568 ze zm.).

2 Ustawa z 19 czerwca 2020 r. o dopłatach do oprocentowania kredytów bankowych udzielanych przedsiębiorcom dotkniętym skutkami COVID-19 oraz o uproszczonym postępowaniu o zatwierdzenie układu w związku z wystąpieniem COVID-19 (Dz. U. z 2020 r. poz. 1086 ze zm.). 
stosowania. Środek ten można określić mianem ochrony wykonywania zawodu, co wydaje się dobrze odzwierciedlać jego charakter i luźne jedynie powiązanie z podstawowymi funkcjami środków zapobiegawczych.

\section{FUNKCJE ŚRODKA}

Już sam cel stosowania środka $\mathrm{z}$ art. 276a k.p.k. wykazuje istotne odmienności w stosunku do pozostałych środków zapobiegawczych. Zgodnie z art. 249 k.p.k. środki te mogą być stosowane w celu zabezpieczenia prawidłowego toku postępowania (funkcja zabezpieczająca) lub wyjątkowo w celu zapobieżenia popełnieniu nowego ciężkiego przestępstwa (funkcja prewencyjna). Trudno dopatrzyć się w omawianym środku istotnego znaczenia z punktu widzenia zabezpieczenia prawidłowego toku postępowania. Niewątpliwie nie ma on powiązania z ryzykiem ucieczki lub ukrycia. Jeśli zaś chodzi o wpływanie na świadków lub inne bezprawne utrudnianie postępowania, to zakaz zbliżania się do pokrzywdzonego na określoną odległość czy kontaktowania się z nim może w jakimś stopniu zapobiegać bezprawnemu wpływowi na świadka. Cel taki może być wszakże realizowany również przez dozór Policji i związane z nim zakazy; w tym zakresie nowy środek stanowi zatem powielenie regulacji art. 275 k.p.k. Natomiast nowością jest zawarty w art. 276a k.p.k. zakaz publikowania treści godzących w prawnie chronione dobra pokrzywdzonego ${ }^{3}$. W tym ostatnim zakresie jednak jeszcze trudniej doszukać się realnej funkcji zabezpieczającej. Należałoby bowiem wykazać, że ewentualne publikacje mogą wpłynąć na zeznania pokrzywdzonego czy innych osób lub inne dowody, co w praktyce będzie trudne. Zakaz publikowania treści ma natomiast ewidentnie spełniać funkcję prewencyjną. Jak wskazano w uzasadnieniu projektu: „Projektowany przepis art. 267a [numer artykułu w projekcie ustawy - A.L.]

\footnotetext{
R. Koper, [w:] Kodeks postępowania karnego. Komentarz, red. A. SAKowicz, Warszawa 2020, s. 772, wskazuje, że z uwagi na otwarty katalog obowiązków związanych z dozorem Policji zawarte w art. 276a zakazy mogły być orzekane już wcześniej. Z uwagą tą można się zgodzić, jednak po raz pierwszy zakaz publikacji określonych treści został wyraźnie wyartykułowany w kodeksie postępowania karnego.
} 
jest odpowiedzią na wielokrotne postulaty środowiska medycznego zapewnienia szczególnej ochrony pracownikom służby zdrowia, którzy są narażeni na ataki zarówno słowne, jak i fizyczne w związku ze swoją pracą. W szczególności przywoływane były ataki na ratowników medycznych pracujących w karetkach pogotowia. W okresie epidemii ataki te przybrały na szczególnej sile w postaci publikacji na forach internetowych danych osobowych lekarzy wraz z „ostrzeżeniami” o konieczności unikania tych osób” ${ }^{\prime}$. Z kolei w $₫ 4$ art. 276a k.p.k. wskazano na potrzeby w zakresie zabezpieczenia prawidłowego biegu postępowania karnego oraz zapewnienia odpowiedniej ochrony pokrzywdzonemu lub osobom dla niego najbliższym. Rzecz jednak w tym, że zgodnie $\mathrm{z}$ art. 249 k.p.k. cel prewencyjny wiąże się z ryzykiem popełnienia nowego, ciężkiego przestępstwa, zaś art. $258 \$ 3$ k.p.k. doprecyzowuje, że chodzi o przestępstwa przeciwko życiu, zdrowiu lub bezpieczeństwu powszechnemu. Natomiast przestępstwa popełniane przez publikowanie treści naruszających prawnie chronione dobra pokrzywdzonego nie będą zwykle - mając na względzie ustawowe zagrożenie - ani ciężkie, ani skierowane przeciwko życiu, zdrowiu czy bezpieczeństwu powszechnemu, nawet jeśli przyjąć, że może to być również dodatkowy przedmiot ochrony. W doktrynie powszechnie przyjmuje się, że przestępstwem ciężkim jest przestępstwo zagrożone karą, której górna granica wynosi co najmniej osiem lat pozbawienia wolności ${ }^{5}$. Tymczasem dla przykładu groźba karalna (art. 190 k.k.) jest zagrożona karą do dwóch lat pozbawienia wolności, zmuszanie (art. 191 k.k.) do lat trzech, zniesławienie lub zniewaga za pomocą środków masowego komunikowania się są zagrożone karą do roku pozbawienia wolności (odpowiednio art. 212

4 Druk sejmowy nr 299A z 27 marca 2020 r., s. 15, http://orka.sejm.gov.pl/Druki9ka.nsf/0/5EDFDA5A0BA099CBC1258538003A6786/\%24File/299-A.pdf (dostęp 20 października 2020 r.).

5 R.A Stefański, Przesłanki tymczasowego aresztowania w nowym kodeksie postępowania karnego, «Wojskowy Przegląd Prawniczy» 3-4/1997, s. 90; P. HofmańSKi, E. SAdZIK, K. ZgryzeK, Kodeks postępowania karnego. Komentarz, I, Warszawa 2011, s. 1450; L.K. PAPRZYCKI, [w:] Kodeks postępowania karnego. Komentarz, red. J. Grajewski, I, Kraków 2006, s. 714; J. SKorupKa, [w:] Kodeks postępowania karnego. Komentarz, red. J. Skorupka, Warszawa 2018, s. 585-586; K. BoratyńsKa, P. CzARNeCKI, R. Koper, [w:] Kodeks..., red. A. SAKowicz, s. 700. 
$\$ 2$ oraz art. $216 \$ 2$ k.k.). Idąc dalej, można byłoby stwierdzić, że takie naruszenie w ogóle nie musi być przestępstwem, lecz może być deliktem cywilnym (art. 23 i 24 k.c.), co czyniłoby środki karnoprocesowe alternatywą do tych przewidzianych $\mathrm{w}$ prawie cywilnym ${ }^{6}$ czy postępowaniu cywilnym7. Takie uregulowanie nasuwa wiele wątpliwości. Po pierwsze, nie wiadomo dlaczego prawo karne procesowe ma przejmować zadania środków cywilnoprawnych. Po drugie, środek zapobiegawczy, nawet mający charakter prewencyjny, nie powinien polegać na zakazie popełnienia przestępstwa, gdyż zakaz popełniania określonych czynów zabronionych wynika wprost z kodeksu karnego. Środek taki może jedynie uniemożliwiać, utrudniać lub zniechęcać do określonego zachowania. W tej sytuacji zakłada się zakazanie przez organ procesowy instrumentami karnoprocesowymi zachowań, które są już zakazane przez prawo karne materialne.

Z kolei czyny z art. 190a k.k., a więc uporczywe nękanie oraz kradzież tożsamości, które są obecnie zagrożone w typie podstawowym karą do ośmiu lat pozbawienia wolności, nie są przestępstwami przeciwko życiu i zdrowiu ${ }^{8}$. Oba powyższe kryteria może spełniać przestępstwo z art. 190a \$3 k.k., którego dodatkowym przedmiotem ochrony jest także życie człowieka9 . Należy jednak zauważyć, że jest to przestępstwo pojawiające się w praktyce niezmiernie rzadko. Z danych statystycznych wynika, że liczba prawomocnych skazań za ten czyn wynosi: w 2011 r. - 1, w 2012 r. - 1, w 2013 r. - 1, w 2014 r. - 3, w 2015 r. - 3, w 2016 r. - 5, w 2017 r. - 1, w 2018 r. - $5^{10}$, stąd można wnioskować, że liczba toczących

\footnotetext{
6 Zob. art. $24 \$ 1$ k.c.

7 Zob. art. $755 \$ 2$ k.p.c.

8 Trudno podzielić pogląd, że w przypadku tych czynów dodatkowym przedmiotem ochrony jest zdrowie człowieka. Por. M. Mozgawa, [w:] Kodeks karny. Komentarz, red. M. Mozgawa, Warszawa 2015, s. 507.

9 Zob. A. Zoll, [w:] Kodeks karny. Część szczególna, II.1: Komentarz do art. 117211a, red. W. Wróbel, A. Zoll, Warszawa 2017, s. 591; S. Hypś, [w:] Kodeks karny. Komentarz, red. A. GrześKowiak, Warszawa 2019, s. 1013.

10 Skazania prawomocne z oskarżenia publicznego - dorośli - według rodzajów przestępstw i wymiaru kary w latach 2008-2018, https://isws.ms.gov.pl/pl/baza-statystyczna/opracowania-wieloletnie/ (dostęp 20 października 2020 r.).
} 
się postępowań w fazie in personam oraz wniesionych aktów oskarżenia również nie jest znaczna.

Ustawodawca wymienił art. 190a k.k. odrębnie w art. 276a § la k.p.k. Nie wpływa to jednak na potrzebę uprawdopodobnienia zaistnienia przesłanki ogólnej i przesłanek szczególnych stosowania środków zapobiegawczych.

Należy zatem stwierdzić, że brak jest korelacji pomiędzy podstawami stosowania środków zapobiegawczych a treścią art. 276a $\$ 1$ i la k.p.k. Przepisy te będą miały zastosowanie w nielicznych przypadkach, takich jak wyżej wskazane. Nie można bowiem przyjąć, że $\$ 1$ i la art. 276a stanowią lex specialis w stosunku do art. 249 i $258 \$ 3$ k.p.k. Polski ustawodawca wprowadził tego typu regulacje szczególne na przykład w art. 277 k.p.k., który zawęża podstawę szczególną stosowania poręczenia majątkowego do obawy ucieczki oraz w art. 26 ust. 2 ustawy o działaniach antyterrorystycznych ${ }^{11}$, który przewiduje, że podstawą stosowania tymczasowego aresztowania na okres do 14 dni może być jedynie uzasadnione podejrzenie popełnienia przestępstwa o charakterze terrorystycznym. Artykuł 276a $\$ 1$ i la nie formułuje jednak odrębnej od art. 249 i 258 \$ 3 k.p.k. zarówno wyłącznej, jak i dodatkowej przesłanki stosowania uregulowanego $\mathrm{w}$ nim środka związanej $\mathrm{z}$ jego celami ${ }^{12}$. Poniżej omówiona sformułowana w art. 276a $\$ 1$ i la przesłanka związana $\mathrm{z}$ cechami osobistymi pokrzywdzonego lub kwalifikacją prawną czynu jedynie zawęża krąg sytuacji, w których stosowanie tego środka jest możliwe przy spełnieniu przesłanki ogólnej i przesłanek szczególnych stosowania środków zapobiegawczych, w tym również przesłanki prewencyjnej wynikającej z art. 249 i $258 \$ 3$ k.p.k. Aby przyjąć inne rozwiązanie, ustawodawca powinien bowiem tak jak w wyżej wymienionych przepisach dać temu wyraz poprzez na przykład wskazanie, że „podstawą zastosowania środka może być także”. Należy jednak zastrzec, że ustawodawca nie ma dowolności w tym względzie. Zapobieżenie popełnieniu przestępstwa jest bowiem przesłanką odrębną od zasadniczego celu procesu, tj. rozstrzygnięcia kwestii odpowiedzial-

11 Ustawa z10 czerwca 2016 r. o działaniach antyterrorystycznych (Dz. U.z2019 r.poz. 796).

12 Odmiennie R. Koper, [w:] Kodeks..., s. 773. 
ności karnej określonej osoby za zarzucany czyn. Cel prewencyjny jest współcześnie uznawany za dopuszczalny przy stosowaniu instytucji karnoprocesowych, w tym środków zapobiegawczych. Jednak trzeba sobie zdawać sprawę, że stosowanie środków przymusu do celów prewencyjnych jest nie tylko ingerencją w prawo do wolności osobistej, swobodę poruszania się, prawo do prywatności lub inne prawa człowieka, lecz także negatywnie wpływa na korzystanie z gwarancji procesowych przez oskarżonego. Należy zaś mieć na uwadze, że jest on osobą, która korzysta $\mathrm{z}$ domniemania niewinności w odniesieniu do zarzuconego przestępstwa. Z tego względu stosowanie środków zapobiegawczych do celów prewencyjnych może mieć miejsce w wyjątkowych przypadkach, uzasadnionych z jednej strony powagą grożącego przestępstwa, $z$ drugiej stopniem ryzyka jego popełnienia ${ }^{13}$. Pojawia się tu zatem test niezbędności, przydatności oraz proporcjonalności sensu stricto. Niedopuszczalne byłoby na przykład pozbawienie jakiejś osoby wolności ze względu na ryzyko popełnienia przez nią w przyszłości kradzieży. Podobnie ograniczenie wolności wypowiedzi może być działaniem nieproporcjonalnym do celu, który zamierza się osiągnąć, o czym będzie niżej mowa.

Zakazanie publikowania na podstawie art. 276a k.p.k. będzie mogło być zatem zasadniczo powiązane jedynie z przesłanką zabezpieczenia prawidłowego toku postępowania, co jak wspomniano, będzie w większości przypadków trudne do wykazania.

\section{ZAKRES PODMIOTOWY OCHRONY}

Środek przewiduje ochronę trzech grup osób:

a. personelu medycznego;

b. osób przybranych personelowi medycznemu;

c. osób pokrzywdzonych czynem z art. 190a k.k.

13 Zob. J. Kosonoga, Dozór Policji jako środek zapobiegawczy w polskim procesie karnym, Warszawa 2008, s. 69; J. Grajewski, Przebieg procesu karnego, Warszawa 2012, s. 133; A. LACH, Prewencja indywidualna w procesie karnym, Warszawa 2020, s. 146-155. 
Pojęcie personelu medycznego zostało użyte w wielu ustawach ${ }^{14}$, jednak nigdzie nie zostało zdefiniowane. Wobec braku definicji ustawowej personelu medycznego należy odwołać się do dorobku piśmiennictwa i judykatury. W piśmiennictwie przez to pojęcie rozumie się lekarzy i inne osoby uczestniczące w procesie udzielania świadczeń zdrowotnych $^{15}$. Należy przyjąć, że pojęcie personelu medycznego jest szersze od użytego w ustawie o działalności leczniczej pojęcia osoby wykonującej zawód medyczny ${ }^{16}$. Obejmuje ono nie tylko osoby wykonujące zawody medyczne, lecz także inne osoby zatrudnione w placówkach medycznych, których praca pozostaje w związku z udzielaniem świadczeń zdrowotnych, na przykład salowe, terapeutów i psychologów zatrudnionych w placówkach medycznych ${ }^{17}$. Takie też podejście przyjęto w uzasadnieniu projektu ${ }^{18}$, wskazując, że: „Pojęcie «opieki medycznej» zawarte w projektowanym art. 267a kpk jest tożsame zakresowo z tym samym pojęciem użytym przez ustawodawcę w art. $123 \$ 1 \mathrm{kk}$. Jest one celowo szersze niż sformułowania lekarz lub pielęgniarka, aby zapewnić ochronę prawnokarną wszelkim osobom wykonującym czynności opieki medycznej”. Chodzi o osoby zatrudnione zarówno w publicznej, jak i prywatnej opiece medycznej ${ }^{19}$.

Osoba przybrana personelowi medycznemu to taka, która nie będąc członkiem tego personelu, na polecenie lub prośbę członka personelu

14 Zob. np. art. 48e i 161 b ustawy z 27 sierpnia 2004 r. o świadczeniach opieki zdrowotnej finansowanych ze środków publicznych (tekst jedn. Dz.U. z 2020 r. poz. 1398) oraz art. 1 ustawy z 14 marca 1985 r. o Państwowej Inspekcji Sanitarnej (tekst jedn. Dz. U. z 2019 r. poz. 59 ze zm.); art. 36 ustawy z 5 grudnia 1996 r. o zawodach lekarza i lekarza dentysty (tekst jedn. Dz. U. z 2020 r. poz. 514 ze zm.).

15 A. Dyszlewska-TARnAwska, [w:] Ustawa o zawodach lekarza i lekarza dentysty. Komentarz, red. L. Ogiegıo, Warszawa 2015, s. 435.

16 Zob. art. 2 ust. 1 pkt 2 ustawy z 15 kwietnia 2011 r. o działalności leczniczej (tekst jedn. Dz. U. z 2020 r. poz. 295 ze zm.).

17 Por. wyrok WSA w Lublinie z 13 grudnia 2011 r., III SA/Lu 653/11, «Legalis» nr 408725.

18 Druk sejmowy nr 299A z 27 marca 2020 r., s. 15, http://orka.sejm.gov.pl/Druki9ka.nsf/0/5EDFDA5A0BA099CBC1258538003A6786/\%24File/299-A.pdf (dostęp 20 października 2020 r.).

19 Ibidem. 
medycznego wykonuje związane z jego zadaniami czynności, na przykład kierowca przewożący członków personelu medycznego czy student pomagający jako wolontariusz w szpitalu. W literaturze trafnie przyjmuje się, że osobą przybraną może być także osoba przydzielona danej osobie do pomocy przez kogoś innego, na przykład przełożonego ${ }^{20}$. Za osobę przybraną można uznać także taką, która z własnej inicjatywy podjęła się pomocy członkowi personelu medycznego, co zostało przez tego ostatniego w sposób wyraźny lub dorozumiany zaaprobowane, na przykład członka rodziny lub sąsiada pomagającego przenieść pacjenta ${ }^{21}$. Nie sposób jednak uznać za taką osoby, która podejmuje się pomocy wbrew woli członka personelu medycznego lub bez jego wiedzy lub akceptacji.

Trzecia kategoria to osoby pokrzywdzone czynem z art. 190a k.k. bez względu na rodzaj wykonywanego zawodu, jeśli tylko pokrzywdzenie było związane z jego wykonywaniem. Jak wskazano w uzasadnieniu projektu nowelizacji dodającej $\$ 1 \mathrm{a}^{22}$ : „Zasadniczym celem projektowanej regulacji jest ochrona tych grup zawodowych, które są szczególnie narażone na różne formy przestępczego nękania. Do takich grup zaliczyć należy m.in. nauczycieli oraz innych pracowników szkolnictwa i edukacji, którzy nierzadko narażeni są na powtarzającą się, nie tylko werbalną, agresję uczniów. Przepis znajdzie również zastosowanie w sytuacjach, w których określone grupy zawodowe padają celem ataków ze względu na okoliczności o charakterze tymczasowym i obiektywnym, takie jak np. panująca epidemia. Zaliczyć do nich można m.in. górników i ich rodziny lub pracowników domów opieki społecznej i hospicjów”. Może być to zatem na przykład nauczyciel nękany za wystawienie negatywnej oceny, urzędnik nękany za wydaną decyzję czy listonosz nękany za doręczenie niechcianej przesyłki urzędowej. Ustawodawca wskazał ogólnie na art. 190a k.k., w związku z czym należy przyjąć, że chodzi nie tylko

20 J. Lachowski, [w:] Kodeks karny. Komentarz, II, red. M. KRóLIKowski, R. ZAWŁocki, Warszawa 2017, s. 11.

21 Por. wyrok SA w Katowicach z 17 maja 2007 r., II AKa 142/07, «Lex» nr 331807.

22 Uzasadnienie druk sejmowy nr 382 z 22 maja 2020 r., s. 27, http://orka.sejm. gov.pl/Druki9ka.nsf/0/5EDFDA5A0BA099CBC1258538003A6786/\%24File/299-A.pdf (dostęp 20 października 2020 r.). 
o przestępstwo uporczywego nękania $z$ art. 190a $\$ 1$ k.k., lecz także kradzież tożsamości z $\$ 2$ tego przepisu oraz (co wszakże, jak wspomniano, w praktyce występuje sporadycznie) typ kwalifikowany tych przestępstw $\mathrm{z}$ art. 190a $\$ 3$ k.k. Zastosowanie środka zapobiegawczego z art. 276a k.p.k. w przypadku kradzieży tożsamości należeć będzie zapewne do rzadkości, znacznie częściej wejdzie w grę uporczywe nękanie.

\section{PrzesŁanki stosowania}

Poza przesłanką ogólną i przesłankami szczególnymi stosowania środków zapobiegawczych warunkiem zastosowania art. 276a k.p.k. jest to, aby przeciwko oskarżonemu toczyło się postępowanie o przestępstwo popełnione przeciwko członkowi personelu medycznego lub osobie mu przybranej lub o czyn z art. 190a k.k. Oznacza to wymóg istnienia takiego szczególnego pokrzywdzonego lub przyjęcie kwalifikacji prawnej z art. 190a k.k., chociażby jako jednego ze zbiegających się przepisów.

Kolejne wymagania to związek pomiędzy zarzucanym przestępstwem a wykonywanymi czynnościami ( $\$ 1)$ albo wykonywanym zawodem (\$ 1a). Ustawodawca nie wymaga, aby zarzucone przestępstwo było popełnione podczas wykonywania obowiązków zawodowych. Zarzut może dotyczyć również przestępstwa popełnionego na przykład po zakończeniu pracy przez pokrzywdzonego czy też podczas jego urlopu. Jak wskazał Sąd Najwyższy w kontekście art. $222 \$ 1$ k.k. „Zwrot «w związku z pełnieniem czynności służbowych» należy rozumieć jako powiązanie zachowania sprawcy z konkretną czynnością podejmowaną lub wcześniej wykonaną przez funkcjonariusza w ramach przysługujących mu kompetencji”, nie jest zatem niezbędna zbieżność czasowa ani miejscowa $^{23}$. Nie zachodzą przesłanki z $\$ 1$ art. 276a k.p.k., jeśli przestępstwo zostało popełnione generalnie z powodu wykonywania przez pokrzywdzonego określonego zawodu (np. bycia lekarzem lub pielęgniarką), pozostaje wówczas ewentualnie zastosowanie $\$$ la tego artykułu, jeśli postępowanie toczy się o czyn z art. 190a k.k. Wyrażenie „W związku”

23 Postanowienie SN z 11 kwietnia 2019 r., III KK 33/18, «OSNKW» 8/2019, poz. 43. 
obejmuje także czyny zabronione popełnione podczas czynności, ustawodawca w przeciwieństwie do art. $222 \$ 1 \mathrm{k} . \mathrm{k}$. nie posłużył się w art. 276a k.p.k. formułą „podczas lub w związku”.

W przypadku członka personelu medycznego zarzucane przestępstwo ma być popełnione w związku z wykonywaniem przez niego czynności opieki medycznej, na przykład badaniem lekarskim, pobraniem próbek do badań, przyjmowaniem do szpitala, rejestracją w przychodni. Nie będzie zatem podstaw do stosowania środka $\mathrm{z}$ art. 276a k.p.k. w przypadku związku z wykonywaniem przez personel medyczny innych czynności, na przykład orzekaniem przez lekarza w komisji dyscyplinarnej lub uczestnictwem w pracach komisji bioetycznej.

W przypadku osoby przybranej odwołano się do przestępstw popełnionych w związku z czynnościami opieki medycznej, do których dana osoba została przybrana. Może to być na przykład przewożenie personelu medycznego lub pacjenta, przenoszenie pacjenta do karetki. Wystarczy sam fakt, że osoba ta została przybrana do wykonania czynności; nie jest wymagane, aby podjęła ona lub usiłowała podjąć te czynności ${ }^{24}$.

Dla odmiany, w sytuacji wskazanej w $\$$ la, a więc w przypadku zarzutu z art. 190a k.k., chodzi o przestępstwo popełnione z powodu wykonywanego przez pokrzywdzonego zawodu. Należy zatem przyjąć, że chodzi nie tylko o przestępstwa popełnione $\mathrm{z}$ powodu wykonywania konkretnych czynności zawodowych, lecz także generalnie z powodu wykonywania określonego zawodu, na przykład sprawca nęka osobę, o której wie, że jest policjantem, komornikiem lub wykonuje inny nielubiany przez sprawcę zawód, natomiast nigdy nie miał kontaktu z czynnościami zawodowymi tej osoby.

\section{ZAKAZY}

Jeśli chodzi o zakaz zbliżania się do pokrzywdzonego na wskazaną odległość oraz zakaz kontaktów z pokrzywdzonym, to można skorzystać

24 J. Lachowski, [w:] Kodeks..., s. 12. 
z dorobku literatury i orzecznictwa na gruncie art. 275 k.p.k. oraz art. $41 \S 1 \mathrm{a}$ i art. $72 \mathrm{k} . \mathrm{k}$.

Zakaz zbliżania się na określoną odległość do pokrzywdzonego musi być skonkretyzowany przez organ procesowy. Określona odległość powinna, z jednej strony, dawać odpowiednią ochronę pokrzywdzonemu, z drugiej, nie stanowić dla oskarżonego niepotrzebnej, zbyt daleko posuniętej dolegliwości. Stąd na przykład dystans 100 czy 200 metrów można uznać w niektórych przypadkach za uzasadniony (zasięg wzroku pozwalający na identyfikację osoby), dystans jednego kilometra jest już trudny do uzasadnienia. Trzeba też mieć na uwadze, czy oskarżony nie mieszka blisko pokrzywdzonego (np. w sąsiednim domu) lub nie musi załatwiać jakichś spraw w miejscu pracy pokrzywdzonego (np. w urzędzie gminy). W tej sytuacji zbyt szeroki zakaz uniemożliwiłby lub co najmniej utrudniłby korzystanie z mieszkania, załatwienie czynności urzędowych czy skorzystanie z należnych świadczeń. Nie ma przeszkód, aby przy określaniu zakazu zbliżania się ustanowić różne odległości dla poszczególnych miejsc przebywania pokrzywdzonego (np. dla pracy i dla domu).

Zakaz kontaktów z pokrzywdzonym może zostać sformułowany w sposób ogólny, a więc w jakiejkolwiek formie lub doprecyzowany poprzez wskazanie form zakazanego kontaktu. Dla przykładu można zakazać kontaktu bezpośredniego (fizycznego) z pozostawieniem możliwości kontaktu telefonicznego lub mejlowego, jeśli jest to konieczne na przykład ze względów osobistych lub zawodowych.

W myśl art. 276a $\$ 3$ k.p.k. zakaz publikacji treści godzących w prawnie chronione dobra pokrzywdzonego, o którym mowa w $\$ 1$ tego przepisu, obejmuje zakaz publikowania i innego udostępniania tych treści niezależnie od tego, czy zostały wytworzone przez oskarżonego czy inną osobę, za pośrednictwem internetowych portali, stanowiących usługę świadczoną drogą elektroniczną w rozumieniu ustawy z 18 lipca 2002 r. o świadczeniu usług drogą elektroniczną 25 . Zawężenie zakazu publikowania do portali internetowych jest niezrozumiałe. Równie dolegliwe może być dla pokrzywdzonego na przykład rozplakatowanie takich

25 Tekst jedn. Dz. U. z 2020 r. poz. 344. 
treści w tradycyjnej formie. Inne udostępnianie nie musi być publiczne, co oznacza na przykład umieszczenie treści na serwerze i udostępnienie do nich hasła dostępu określonym osobom czy też przesłanie środkami komunikacji oferowanymi przez portale internetowe. Pojęcie „treści” nie określa rodzaju informacji, może to być zatem zarówno tekst, jak i rysunki, nagranie głosu, zdjęcia lub filmy.

Pojawia się też pytanie o relację pomiędzy zakazem publikowania a wolnością ekspresji gwarantowaną przez art. 10 EKPC. Ogólny zakaz publikacji czy też zakaz publikacji w określonym serwisie mógłby być uznany za nieproporcjonalną ingerencję, stąd pojawia się konieczność sprecyzowania w postanowieniu, o jakie treści i kogo dotyczące chodzi. W sprawie Cengiz i inni p. Turcji ${ }^{26}$ ETPC uznał za naruszenie art. 10 EKPC zablokowanie skarżącemu dostępu do serwisu YouTube w związku z toczącym się postępowaniem. Trybunał zauważył, że skarżący został pozbawiony możliwości korzystania z serwisu przez dłuższy czas, a jako aktywnego użytkownika serwisu pozbawiono go prawa do otrzymywania i przekazywania informacji i idei. Podobnie w sprawie Ahmet Yıldırım p. Turcji ${ }^{27}$ sąd krajowy zadecydował o zablokowaniu dostępu skarżącego do Google Sites. Trybunał uznał, że nie był to całkowity zakaz korzystania z Internetu, lecz jedynie jego ograniczenie. Jednak ograniczenie to było daleko idące. Sąd turecki nie rozważył, czy nie byłoby wystarczające wykorzystanie mniej ingerującego w prawo $\mathrm{z}$ art. 10 EKPC środka. Było to w dużej mierze konsekwencją regulacji prawa krajowego, które nie nakładało na sądy obowiązku rozważenia, czy ogólna blokada dostępu do Google Sites była uzasadniona. Sądy tureckie powinny zaś zwrócić uwagę na to, że środek taki uniemożliwi dostęp do dużej ilości informacji, bezpośrednio dotykając praw użytkowników Internetu i wywołując istotny efekt uboczny. Nie ma wątpliwości, że za naruszenie art. 10 EKPC zostałby uznany ogólny zakaz publikowania treści w Internecie czy korzystania z Internetu.

26 Wyrok z 1 grudnia 2015 r., skargi nr 48226/10 i 14027/11.

27 Wyrok z 18 grudnia 2012 r., skarga nr 3111/10. 
Organ procesowy powinien zatem w każdym postanowieniu o zakazie publikowania wskazać, o jakiego rodzaju treści dotyczące pokrzywdzonego chodzi i jakie miejsca zakaz publikacji obejmuje.

\section{PoręCzenie majątKowe}

Zakazy z art. 276a k.p.k. mogą być powiązane z poręczeniem majątkowym. Należy zauważyć, że poręczenie majątkowe stosowane w związku $\mathrm{z}$ art. 276a zmienia swój charakter. Zgodnie z regulacją art. $268 \$ 1$ k.p.k. przepadek poręczenia jest możliwy tylko w sytuacji ukrycia się lub ucieczki oskarżonego albo innego bezprawnego utrudniania postępowania. Tymczasem w przypadku poręczenia zastosowanego na podstawie art. 276a k.p.k., przepadek poręczenia jest możliwy w sytuacji niezastosowania się do zakazów, czyli na przykład opublikowania treści godzących w dobra pokrzywdzonego. Ze środka służącego zabezpieczeniu prawidłowego toku postępowania poręczenie majątkowe staje się w dużej mierze środkiem prewencyjnym, który ma na celu niedopuszczenie do popełnienia przestępstwa. Jak wskazano w uzasadnieniu projektu $^{28}$ : „Potencjalny przepadek poręczenia w wielu sytuacjach będzie działał bardziej motywująco na oskarżonych niż dozór policyjny, a będzie mniej surowy niż tymczasowe aresztowanie".

\section{OKres Stosowania}

W myśl art. 276a $\$ 4$ k.p.k., czas stosowania zakazów, o których mowa $\mathrm{w} \$ 1$, określa się przy uwzględnieniu potrzeb w zakresie zabezpieczenia prawidłowego biegu postępowania karnego oraz zapewnienia odpowiedniej ochrony pokrzywdzonemu lub osobom dla niego najbliższym. $\mathrm{W}$ postępowaniu przygotowawczym prokurator może zastosować ten

28 Druk sejmowy nr 299A z 27 marca 2020 r., s. 15, http://orka.sejm.gov.pl/Druki9ka.nsf/0/5EDFDA5A0BA099CBC1258538003A6786/\%24File/299-A.pdf (dostęp 20 października 2020 r.). 
środek do sześciu miesięcy. Należy przyjąć, że chodzi o łączny czas stosowania środka, a więc prokurator może go zastosować więcej niż jeden raz, jeśli suma okresów stosowania nie przekroczy sześciu miesięcy. Przedłużenia w postępowaniu przygotowawczym ponad sześć miesięcy może dokonać sąd rejonowy w okręgu, w którym toczy się postępowanie na wniosek prokuratora. Stosowanie środka w postępowaniu sądowym nie jest ograniczone czasowo poza ogólnym wymogiem z $\$ 4$. Oddanie przedłużenia stosowania środka w postępowaniu przygotowawczym do kompetencji sądu należy uznać za trafne, ponieważ zwiększa kontrolę nad stosowanym środkiem i wymusza obiektywne zweryfikowanie przesłanek jego stosowania po upływie sześciu miesięcy.

\section{Podsumowanie}

Podsumowując przeprowadzone rozważania, można stwierdzić, że art. 276a k.p.k. jest mało przemyślanym środkiem przymusu, niespójnym z przesłankami stosowania środków zapobiegawczych oraz pozostałymi środkami zapobiegawczymi. Stąd można przypuszczać, że jego praktyczne znaczenie będzie ograniczone, tym bardziej że określone w nim zakazy mogą być orzeczone w ramach dozoru Policji. Należy też wskazać, że wprowadzając do kodeksu postępowania karnego nowe środki przymusu, ustawodawca powinien rozważyć, czy właściwszą drogą do osiągnięcia celu nie jest prawo cywilne lub administracyjne. Proces karny jako całość i poszczególne instytucje karnoprocesowe nie powinny być bowiem bez spełnienia wymogów niezbędności, przydatności i proporcjonalności sensu stricto wykorzystywane do celów, które niewiele mają wspólnego z rozstrzygnięciem o przedmiocie procesu, a mogą negatywnie wpłynąć na rzetelność tego procesu. 
OCHRONA WYKONYWANIA ZAWODU JAKO NOWY ŚRODEK ZAPOBIEGAWCZY W KODEKSIE POSTĘPOWANIA KARNEGO

\section{Streszczenie}

Przedmiotem opracowania jest nowo wprowadzony do kodeksu postępowania karnego środek zapobiegawczy z art. 276a, który można określić mianem ochrony wykonywania zawodu. Autor dokonuje oceny celowości jego wprowadzenia, a także funkcji, zakresu podmiotowego ochrony, przesłanek stosowania, rodzaju orzekanych zakazów, powiązania z poręczeniem majątkowym oraz okresu stosowania. Wypowiada się krytycznie co do potrzeby wprowadzenia środka oraz wskazuje na brak spójności z przesłankami stosowania środków zapobiegawczych oraz systemem dotychczas obowiązujących środków zapobiegawczych.

\section{A New Preventive Measure in the Polish Code of Criminal Procedure for the Protection of Professional Practice}

\section{Summary}

The subject of the study is a new preventive measure recently introduced in Art. 276a of Kodeks postępowania karnego (the Polish Code of Criminal Procedure) for the protection of professional practice. I review the need for such a measure and its purpose, the scope of protection it offers, the grounds for its application, the type of injunctions associated with the measure, the associated surety or financial guarantee, and the period of time for which such an injunction may remain in force. I am critical of the need for such a measure and note its inconsistency with the grounds generally used in the Polish Code of Criminal Procedure for the application of injunctions.

Słowa kluczowe: proces karny; środki zapobiegawcze; prewencja. Keywords: criminal proceedings; preventive measure; prevention. 


\section{Literatura}

Grajewski J., Przebieg procesu karnego, Warszawa 2012.

Hofmański P., SAdZik E., Zgryzek K., Kodeks postępowania karnego. Komentarz, I, Warszawa 2011.

Kodeks karny. Część szczególna, II.1: Komentarz do art.117-211a, red. W. WRóBEL, A. ZoLL, Warszawa 2017.

Kodeks karny. Komentarz, red. A. GrześKowiak, Warszawa 2019.

Kodeks karny. Komentarz, red. M. MozgawA, Warszawa 2015.

Kodeks karny. Komentarz, II, red. M. KróLIKowsкi, R. ZAwŁocki, Warszawa 2017. Kodeks postępowania karnego. Komentarz, red. A. SAKowicz, Warszawa 2020. Kodeks postępowania karnego. Komentarz, I, red. J. GraJewski, Kraków 2006. Kodeks postępowania karnego. Komentarz, red. J. SKonUPKA, Warszawa 2018.

Kosonoga J., Dozór Policji jako środek zapobiegawczy w polskim procesie karnym, Warszawa 2008.

LACH A., Prewencja indywidualna w procesie karnym, Warszawa 2020.

Stefański R.A., Przesłanki tymczasowego aresztowania w nowym kodeksie postępowania karnego, «Wojskowy Przegląd Prawniczy» 3-4/1997, s. 77-93.

Ustawa o zawodach lekarza i lekarza dentysty. Komentarz, red. L. OgiegŁo, Warszawa 2015. 